\title{
Knowledge and attitudes of Jordanian nursing students toward children's pain assessment and management: A cross-sectional study
}

\author{
Omar Al Omari * \\ Faculty of Nursing, Jerash University, Jerash, Jordan
}

Received: August 17, 2015

DOI: $10.5430 /$ jnep.v6n3p51

\author{
Accepted: November 10, $2015 \quad$ Online Published: November 22, 2015 \\ URL: http://dx.doi.org/10.5430/jnep.v6n3p51
}

\begin{abstract}
Successful pain assessment and management require nurses with sufficient knowledge and appropriate attitudes. A cross-sectional study was conducted to test the nursing students' knowledge and attitudes toward children's pain management across three private universities in Jordan. A convenient sample of 101 nursing students completed the Paediatric Nurses' Knowledge and Attitudes Survey (PNKAS). The total mean score on the PNKAS scale was $18.36 \%$ (SD = +6.30), with a minimum score of 8 and a maximum score of 40. The results showed that Jordanian nursing students have poor knowledge and attitudes towards paediatric pain assessment and management. Jordanian nursing students need more educational materials throughout their study plans and curriculums in regards to paediatric pain assessment and management.
\end{abstract}

Key Words: Pain assessment, Pain management, Nursing students

\section{INTRODUCTION}

Relieving children pain has perceived as a crucial public health issue that needs immediate global attention ${ }^{[1]}$ since failing to manage pain can lead to economic and human burden on patients, their families, and society. ${ }^{[2]}$ In the United Kingdom $8 \%$ of the young population suffers from severe pain, ${ }^{[3]}$ and in Australia $67 \%$ of the population aged 15 years or more complains of bodily pain. ${ }^{[4]}$ The cost of responding to chronic pain was $\$ 34.3$ billion in Australia in 2007, ${ }^{[5]}$ and is a sum of between $\$ 560$ and $\$ 635$ billion annually in the United States. ${ }^{[2]}$ Experiences of acute or/and chronic pain have detrimental physiological and psychological effects on one's life. ${ }^{[6-8]}$ For example, children who experience chronic pain may complain of frequent school absenteeism and withdraw from social life. ${ }^{[9,10]}$ Furthermore, patients who experience acute postoperative pain can complain of delayed wound healing, deep vein thrombosis, and atelectasis. ${ }^{[11]}$ Psychological effects of pain include "fear", "anxiety", "distress", "sleep disturbance", "reduced coping", and "developmental regression". ${ }^{[6,8]}$ On the other side, controlling pain can enhance patients' quality of life, increase their satisfaction, decrease the length of stay in hospitals, reduce hospital costs, and accelerate the healing process. ${ }^{[8,12-15]}$

Several factors have been found to contribute to inadequate pain assessment and management in children. ${ }^{[16-18]}$ These factors include lack of knowledge, poor communication between children and/or families from one side and nurses from the other side, misconceptions and negative attitudes that nurses have about pain in children. Organisational culture is also another important factor come to play. ${ }^{[16-18]}$ One of the recommended solutions to overcome these difficulties, nurses are required to be prepared during their undergradu-

*Correspondence: Omar Al Omari, RN, Ph.D; Email: o.alomari@jpu.edu.jo; Address: Faculty of Nursing, Jerash University, Jerash, Jordan. 
ate studies with necessary pain assessment and management knowledge.

Pain management in Jordan is not up to optimal standards, as statistics have shown that pain-relieving drugs prescribed to Jordanian patients irrespective of their age are less compared with rest of other countries, and too many children suffer of pain. ${ }^{[19]}$ Jordan is also not included among the top 50 countries on the global level for pain management. ${ }^{[19]}$ There is limited research and a lack of committees that take care of pain in Jordan, as the lonely pain society committee established late in 2010. ${ }^{[20]}$ Therefore, too many children have to suffer pain. Two recent studies were conducted related to nursing students' knowledge and attitudes toward pain management in Jordan. ${ }^{[21,22]}$ Results showed that nursing students had inadequate knowledge and negative attitudes toward pain management. However, these two studies examined nursing students' knowledge and attitudes toward pain management in adults and children patients in public universities without including the wide spread of private ones. Therefore, there is a need to recruit students from private universities and assess their knowledge and attitudes towards children pain management in particular as this stage of development needs particular knowledge level.

Nurses who are in close contact with patients and the primary care providers to the children are responsible for creating a pain-free journey during the treatment. ${ }^{[23]}$ In order to do this, nurses must be prepared during their undergraduate studies with necessary pain assessment and management knowledge and have positive attitudes towards pain management. ${ }^{[21,24]}$ A few studies have tested the level of pain assessment and management knowledge among nursing students, and they found that nursing students lack appropriate knowledge. ${ }^{[23,25-27]}$ Previous research alluded to the importance of nurses to have appropriate knowledge regarding pain during their study and integrating pain management topic as a part of nursing syllabus. ${ }^{[21,24]}$ However, in Jordan, lecturers devote only a small proportion of the child health nursing curriculum (theory) to pain management. ${ }^{[22]}$ That is, only one or two lectures, of the total 48 course credit hours are devoted to this topic. The impact of this on the level of nursing students' knowledge of children's pain management has never been tested in Jordan as only literature search revealed only two broad studies. ${ }^{[21,22]}$ Globally, some research has found that pain assessment and management are not adequately addressed in nursing and medical undergraduate curricula. ${ }^{[27-30]}$ Thus, there is a need to study nursing students' knowledge of children's pain management. The current study aimed at testing the knowledge and attitudes of fourth-year nursing students toward children's pain management across three private universities.

\section{METHODS}

\subsection{Design}

A cross-sectional study was conducted to assess nursing students' knowledge and attitudes toward children pain management across three private universities. The data were collected between January and December 2014. A crosssectional design was considered because it is inexpensive and provides quick snapshot of the phenomena under study at a fixed point. ${ }^{[31,32]}$

\subsection{Participants and setting}

A convenience sampling technique was used to recruit nursing students from three private universities in Jordan. All three universities share similar educational systems, rules, and regulations and follow the Ministry of Higher Education accreditations. For inclusion in this study, the participants must be willing to participate in this study; to be enrolled student at one of the universities with a current ID card; nursing students who have successfully completed third year of their undergraduate nursing study because third year students are expected to be completing major part of their hospitals clinical training and already taught child health nursing course, and had successfully finished the child health nursing core courses. To approach potential participants, flyers were attached to student's notice board at nursing faculties to inform students about this research and students who met the inclusion criteria and were interested to participate in this study contacted the researcher and filled the questionnaire. Of a total 170 students who met the inclusion criteria at the three private universities, $101(59.4 \%)$ agreed to take part in this study.

\subsection{Ethical approval}

Ethical approval to conduct this study was obtained from appropriate ethics committees under the condition of keeping the names of the universities anonymous in any publishable research to save their reputations in front of other competitive universities in Jordan. Participation was voluntary. All participants were asked to sign consent forms after reading an information sheet. In the information sheet, the participants' anonymity and their right to withdraw from the study at any stage were emphasised.

\subsection{Questionnaire}

Paediatric Nurses' Knowledge and Attitudes Survey Regarding Pain (PNKAS) was used to depict nurses students' knowledge and attitudes toward children in pain. This tool was developed by Manworren in 1998 to test nurses' knowledge and attitudes toward children in pain. ${ }^{[33]}$ Test re-test reliability ( $r=.67$ ) was established, and Cronbach's alpha was 0.75 , with a range of " 0.75 to 0.78 , which displayed an acceptable 
level of internal consistency. The researcher used the original English form of the questionnaire, as English is the language of study at all nursing faculties in Jordan.

\subsection{Data analysis}

Data were analysed using the statistical package SPSS version 17.01 for Windows (SPSS Inc., 2007). Descriptive statistics (frequency, mean, and standard deviation) were used to describe sample characteristics, and inferential statistics (Mann-Whitney) were used to determine whether there were any significant differences between the subgroups in regards to total PNKAS score at sig level $<.05$.

\section{RESUlts}

One hundred and seventy anonymous questionnaires were distributed to the nursing students across the three universities, of which only 101 completed questionnaires were returned, giving a response rate of $59 \%$. The majority of the participants were female $(68.3 \%)$, with an average age of 21 years and 1 to 3 years of working experience. The nursing students' characteristics are presented in Table 1.

Table 1. Characteristics of nursing students $(n=101)$

\begin{tabular}{lc}
\hline Item & n (\%) \\
\hline Age $(\mathrm{M}=21, \mathrm{SD}=1.26)$ & $32(31.7)$ \\
Gender & $69(68.3)$ \\
Male & \\
Female & $91(90.1)$ \\
Work experience in hospitals (range: 1-3 years) & $10(9.9)$ \\
Yes & \\
No & $9(8.9)$ \\
Did you receive any official pain management training courses outside the university? & $92(91.1)$ \\
Yes & \\
No & $32(31.7)$ \\
Did you receive any pain management courses in any other units EXCEPT the child health nursing unit? \\
Yes & $69(68.3)$ \\
No & \\
\hline
\end{tabular}

The nursing students were asked to respond to a questionnaire composed of 40 questions to evaluate their knowledge and attitude toward children's pain management. The range of possible scores for the PNKAS was between 0 and 42. In general, the survey results showed that Jordanian nursing students have poor knowledge and attitudes toward children's pain management as reflected by their PNKAS scores. The participants' mean correct score for the entire questionnaire was $18.36 \%(\mathrm{SD}=6.30)$, with a minimum score of 8 and a maximum score of 40 . Only $23.7 \%$ (24) of participants obtained a score of 21 or more out of 42 . None of the nursing students achieved complete correct responses, and of the 42 items in the PNKAS, the participants were able to answer 18 items with a correct answer rate of more than $50 \%$. About $70 \%(n=71)$ of the nursing students answered the item "Children who will require repeated painful procedures (i.e., daily blood draws) should receive maximum treatment for the pain and anxiety of the first procedure to minimise the development of anticipatory anxiety before subsequent procedures" correctly, and $88.1 \%$ (89) of them responded to question 38 incorrectly. Descriptive information of the top 10 questions answered correctly and incorrectly by participants

Published by Sciedu Press are presented in Tables 2 and 3, respectively.

Inferential statistics and, in particular, the Mann-Whitney test were used to determine whether a significant variation among subgroups existed. The results were considered significant if the $P$ value was less than .05 . The results showed that there was no significant variation among the subgroups in regards to PNKAS scores (see Table 4).

\section{Discussion AND CONCLUSION}

The aim of this study was to evaluate current fourth-year nursing students' knowledge and attitude towards pain management in children. The results of this study showed that Jordanian nursing students lack the appropriate knowledge and attitudes toward children's pain management when compared against most nursing standards (less than $85 \%$ ). ${ }^{[34]}$ This result is congruent with previous studies. ${ }^{[22,23,27,35,36]}$ However, Jordanian nursing students still have a low score compared with their counterparts in other developed countries, such as Canada, the United States, and Ireland. ${ }^{[34,36-41]}$ This may refer to the limited hours in curricula devoted to teach the pain management topic. Furthermore, lecturers in Jordan, who teach pain management, teach using traditional 
methods (lectures). That is, students have to memorise bulk of information about pain assessment and management and this information is at risk of loss given that they are not using it. There is a need to include more up-to-date teaching methods, and incorporate theory with practice in order to make pain management learning experience more interesting topic that eases students' understanding and minimizes the risk of information loss.

The current research shows that nursing students were weak in the areas of pain assessment and pharmacological pain management and when Opioid addiction can occur. This is not limited to nursing students in Jordan. A recent Turkish study found similar results when most Turkish nurses answered questions related to addiction and pharmacology incorrectly. ${ }^{[42]}$ Other studies reported that nurses have a knowledge deficit regarding pain medication, ${ }^{[11,43,44]}$ which hinder nurses' abilities for providing patients with optimal pain assessment and management options. ${ }^{[34]}$ Generally, nurses have limited pharmacological skills and knowledge in the area of drug prescribing and administration. ${ }^{[45,46]}$ In particular, nurses' students believe that they are unable to provide safe medication care. ${ }^{[4]}$ That is because pharmacological treatment skills take place in clinical settings rather than in closed classes. ${ }^{[46]}$ Nursing students need to be equipped with pharmacological knowledge and skill to deliver safe medication care. ${ }^{[48]}$ There is a need to integrate new teaching methods and put more emphases on pharmacological knowledge while students are in clinical settings.

Table 2. Top 10 questions frequently answered correctly by participants

\begin{tabular}{|c|c|c|c|}
\hline $\begin{array}{l}\text { Number of questions as } \\
\text { mentioned in the survey }\end{array}$ & Questions & $\mathbf{N}$ & $\%$ \\
\hline 8. & $\begin{array}{l}\text { Children who will require repeated painful procedures (i.e., daily blood draws) } \\
\text { should receive maximum treatment for the pain and anxiety of the first procedure to } \\
\text { minimise the development of anticipatory anxiety before subsequent procedures. }\end{array}$ & 71 & 70.3 \\
\hline 5. & Comparable stimuli in different people produce the same intensity of pain. & 70 & 69.3 \\
\hline 27. & $\begin{array}{l}\text { The recommended route of administration of opioid analgesics to children with } \\
\text { brief, severe pain of sudden onset, e.g., trauma or postoperative pain is... }\end{array}$ & 70 & 69.3 \\
\hline 6. & $\begin{array}{l}\text { Ibuprofen and other non-steroidal anti-inflammatory agents are NOT effective } \\
\text { analgesics for bone pain caused by metastases. }\end{array}$ & 66 & 65.3 \\
\hline 22. & $\begin{array}{l}\text { After the initial recommended dose of opioid analgesic, subsequent doses should be } \\
\text { adjusted in accordance with the individual patient's response. }\end{array}$ & 62 & 61.4 \\
\hline 24. & $\begin{array}{l}\text { Giving children/adolescents sterile water by injection (placebo) is often a useful test } \\
\text { to determine if the pain is real. }\end{array}$ & 61 & 60.4 \\
\hline 20. & $\begin{array}{l}\text { Based on one's religious beliefs, a child/adolescent may think that pain and } \\
\text { suffering are necessary. }\end{array}$ & 59 & 58.4 \\
\hline 2. & $\begin{array}{l}\text { Because of an underdeveloped neurological system, children under } 2 \text { years of age } \\
\text { have decreased pain sensitivity and limited memory of painful experiences. }\end{array}$ & 57 & 56.4 \\
\hline 3. & $\begin{array}{l}\text { If the infant/child/adolescent can be distracted from his pain, this usually means that } \\
\text { he is not experiencing a high level of pain. }\end{array}$ & 57 & 56.4 \\
\hline 28. & $\begin{array}{l}\text { Which of the following analgesic medications is considered the drug of choice for } \\
\text { the treatment of prolonged moderate to severe pain for children with cancer? }\end{array}$ & 55 & 54.5 \\
\hline
\end{tabular}

Failing to properly assess and manage a child's pain will impact the physical and psychosocial dimensions of the child and his family. For example, patients with pain may experience real distress, ${ }^{[49,50]}$ which may compromise the quality of care nurses offer. ${ }^{[51]}$ Therefore, preparing nursing students and providing them with the necessary pain management assessment knowledge should be on the top of nursing faculties' priorities.

Although the level of education and years of experience were shown to significantly affect nurses' knowledge and attitudes toward pain management in previous studies, ${ }^{[42,43,52]}$ the results of the current study did not support these previous findings. No significant correlation among level of education, years of experience, and nursing students' level of knowledge measured by PNKAS scores was found. In this regard, several other studies share similar findings with the current study. ${ }^{[25,27,36]}$ The contradiction between previous studies findings creates a gray area to further investigate the impact of these variables on nursing knowledge and attitude. 
Table 3. Top 10 questions frequently answered Incorrectly by participants

\begin{tabular}{|c|c|c|c|}
\hline $\begin{array}{l}\text { Number of question as } \\
\text { mentioned in the survey }\end{array}$ & Question & $\mathbf{N}$ & $\%$ \\
\hline 38. & $\begin{array}{l}\text { Narcotic/opioid addiction is defined as psychological dependence accompanied by } \\
\text { overwhelming concern with obtaining and using narcotics for psychic effect, not for } \\
\text { medical reasons. It may occur with or without the physiological changes of tolerance to } \\
\text { analgesia and physical dependence (withdrawal). } \\
\text { Using this definition, how likely is it that opioid addiction will occur as a result of } \\
\text { treating pain with opioid analgesics? Circle the number closest to what you consider the } \\
\text { correct answer. }\end{array}$ & 89 & 88.1 \\
\hline 39.A & $\begin{array}{l}\text { Patient A: Andrew is } 15 \text { years old and this is his first day following abdominal surgery. } \\
\text { As you enter his room, he smiles at you and continues talking and joking with his visitor. } \\
\text { Your assessment reveals the following information: } \mathrm{BP}=120 / 80 ; \mathrm{HR}=80 ; \mathrm{R}=18 \text {; on a } \\
\text { scale of } 0 \text { to } 10 \text { ( } 0=\text { no pain/discomfort, } 10=\text { worst pain/discomfort), he rates his pain as } \\
8 \text {. } \\
\text { On the patient's record you must mark his pain on the scale below. Circle the number } \\
\text { that represents your assessment of Andrew's pain. }\end{array}$ & 79 & 78.2 \\
\hline 39.B & $\begin{array}{l}\text { Your above assessment is made two hours after he received morphine } 2 \text { mg IV. After he } \\
\text { received the morphine, his pain ratings every half hour ranged from } 6 \text { to } 8 \text { and he had no } \\
\text { clinically significant respiratory depression, sedation, or other untoward side effects. He } \\
\text { has identified } 2 \text { as an acceptable level of pain relief. His physician's order for analgesia } \\
\text { is "morphine IV 1-3 mg q1h PRN pain relief." Check the action you will take at this } \\
\text { time: }\end{array}$ & 79 & 78.2 \\
\hline 31. & $\begin{array}{l}\text { A child with chronic cancer pain has been receiving daily opioid analgesics for two } \\
\text { months. The doses increased during this time period. Yesterday the child was receiving } \\
\text { morphine } 20 \mathrm{mg} \text { /hour intravenously. Today he has been receiving } 25 \mathrm{mg} / \text { hour } \\
\text { intravenously for three hours. The likelihood of the child developing clinically } \\
\text { significant respiratory depression is }\end{array}$ & 78 & 77.2 \\
\hline 26 & $\begin{array}{l}\text { The recommended route of administration of opioid analgesics to children with } \\
\text { prolonged cancer-related pain is }\end{array}$ & 75 & 74.3 \\
\hline 1. & $\begin{array}{l}\text { Observable changes in vital signs must be relied upon to verify a child's/adolescent's } \\
\text { statement that he has severe pain. }\end{array}$ & 75 & 74.3 \\
\hline 17 & Young infants, less than six months of age, cannot tolerate opioids for pain relief. & 72 & 71.3 \\
\hline 40.A & The most accurate judge of the intensity of the child's/adolescent's pain is & 69 & 68.3 \\
\hline 40.B & $\begin{array}{l}\text { Your above assessment is made two hours after he received morphine } 2 \text { mg IV. After he } \\
\text { received the morphine, his pain ratings every half hour ranged from } 6 \text { to } 8 \text { and he had no } \\
\text { clinically significant respiratory depression, sedation, or other untoward side effects. He } \\
\text { has identified } 2 \text { as an acceptable level of pain relief. His physician's order for analgesia } \\
\text { is "morphine IV 1-3 mg q1h PRN pain relief." Check the action you will take at this } \\
\text { time: }\end{array}$ & 68 & 67.3 \\
\hline 29 & $\begin{array}{l}\text { Which of the following IV doses of morphine administered would be equivalent to } \\
15 \mathrm{mg} \text { of oral morphine? }\end{array}$ & 67 & 66.3 \\
\hline
\end{tabular}

Many factors contribute to nursing students' poor knowledge and attitudes toward pain management. Firstly, at the moment, pain assessment and management as a topic is not adequately integrated as a part of nursing courses. A recent British report indicated that pain education represents less than $1 \%$ of the curricula in health care professions. ${ }^{[53]}$ Several other investigators found that in current undergraduate nursing curricula, there is limited information on pain assessment and management available to undergraduate stuPublished by Sciedu Press dents. ${ }^{[28,29,35,54,55]}$ Twycross ${ }^{[56]}$ found that students receive only two class hours of pain education with more focus on pharmacological treatment. Secondly, nursing faculty members have limited knowledge regarding pain management. A recent American study found that nursing faculty scored only 70 out of 100 in Pain Knowledge and Attitudes Survey. ${ }^{[25]}$ Lastly, poor teaching methods are being used to deliver pain assessment and management education. ${ }^{[57]}$ 
Table 4. The relationship between participants' demographics and their total scores

\begin{tabular}{|c|c|c|c|c|}
\hline Variable & $\mathbf{n}$ & Mean & $\mathbf{z}$ & $P$ value \\
\hline \multicolumn{5}{|l|}{ Gender } \\
\hline Male & 32 & 47.28 & -.872 & .383 \\
\hline Female & 69 & 52.72 & & \\
\hline \multicolumn{5}{|c|}{ Work experience in hospitals (range: $1-3$ years) } \\
\hline Yes & 91 & 50.12 & -.913 & .361 \\
\hline No & 10 & 59 & & \\
\hline \multicolumn{5}{|c|}{ Official pain management training outside university } \\
\hline Yes & 9 & 62.56 & -1.244 & .214 \\
\hline No & 92 & 49.87 & & \\
\hline \multicolumn{5}{|c|}{ Did you receive pain education as part of course syllabuses outside the paediatric course? } \\
\hline Yes & 32 & 49.77 & -.289 & .772 \\
\hline No & 69 & 51.57 & & \\
\hline
\end{tabular}

In light of the aforementioned factors, an immediate intervention is required; successful pain assessment and management require nurses with sufficient knowledge and appropriate attitudes. ${ }^{[58]}$ In order to achieve this, there is a need to increase the proportion of pain management courses, as at the moment pain management is interwoven as a individual lectures integrated within nursing courses. Nursing schools are required to critically evaluate their current curricula in the arena of pain assessment and management. Moreover, they need to revaluate the current teaching methods available to deliver pain education to students. In order to do this, faculty members should seek help from experienced pain nurses and should review and adhere to the International Association for the Study of Pain Curriculum Outline on Pain for Nursing. ${ }^{[59]}$ Nursing students need role models from nursing faculties in the clinical area. Clinical instructors need to stress the practice of frequent pain assessment and evaluation in order to be part of nursing students' everyday practices. Hence, faculty members need to be knowledgeable and equipped with modern teaching techniques to influence nursing students. Furthermore, students and post graduates may need to enrol in post qualification pain assessment and management courses in order to improve their pain management knowledge.

This study has several limitations. Most of the participants had some work experience, which may produce biased re- sults. That is, nurses with more work experience are possibly having more knowledge compared with those who have less work experience. However, participants in this study still show a poor knowledge regarding pain assessment and management regardless of their work experience. Furthermore, this study offers a snapshot of the situation in Jordan, and its results cannot be generalised to the entire population because the study consisted of a convenience sample of three private universities and ignored the wide-spread public universities. However, this study can provide decision makers and educators insights about the importance of developing nursing curricula that includes more information about pain assessment and management. Further research is required to confirm the current research findings and to investigate the reasons behind the low grade marks of nursing students in paediatric pain management. Interventional studies are also needed to evaluate the impact of applying educational programmes on nursing students' knowledge and attitudes.

In conclusion, PNKAS showed that Jordanian nursing students' knowledge are not up to standards and it needs further development. This signifies the need for reviewing the current nursing curricula and educating nursing students more about pain assessment and management.

\section{Conflicts of Interest Disclosure}

The author declares that there is no conflict of interest.

\section{REFERENCES}

[1] Finley GA, et al. Why children's pain matters. International Association for the Study of Pain: Pain Clinical Updates. 2005; 13(4) 1-6.

[2] Ung A, et al. Assessing knowledge, perceptions and attitudes to pain management among medical and nursing students: A review of the literature. British Journal of Pain. 2015.

[3] Price C, Hoggart B, Olukoga O. National Pain Audit Final Report 2010-2012. 2012. Available from: http://www.nationalpainau dit.org/media/files/NationalPainAudit-2012.pdf

[4] Australian Bureau of Statistics. Facts at your Fingertips: Health, 2011-2012. 2012. Available from: http://www.abs.gov.au/aus 
stats/abs@.nsf/Lookup/4841. OChapter 12011

[5] The MBF Foundation. The high price of pain: The economic impact of persistent pain in Australia. 2007. Available from: http://www.painaustralia.org.au/images/pain_a ustralia/MBF\%20Economic\%20Impact.pdf

[6] Hutchison RW. Challenges in acute post-operative pain management. American Journal of Health-System Pharmacy. 2007; 64(6 Supplement 4): S2-S5. PMid:17353557 http://dx.doi.org/10.2146 /ajhp060679

[7] Kehlet H, Jensen TS, Woolf CJ. Persistent postsurgical pain: Risk factors and prevention. The Lancet. 2006; 367(9522): 1618-1625. http://dx.doi.org/10.1016/S0140-6736(06)68700-X

[8] Twycross A, Dowden S, Bruce L. Managing pain in children: A clinical guide. Oxford: John Wiley \& Sons; 2009. PMid:19425397 http://dx.doi.org/10.1002/9781444322743

[9] Oddson BE, Clancy CA, McGrath PJ. The role of pain in reduced quality of life and depressive symptomology in children with spina bifida. The Clinical Journal of Pain. 2006; 22(9): 784789. PMid:17057560 http://dx.doi.org/10.1097/01.ajp. 00 $00210929.43192 .5 \mathrm{~d}$

[10] Palermo TM. Impact of recurrent and chronic pain on child and family daily functioning: A critical review of the literature. Journal of Developmental \& Behavioral Pediatrics. 2000; 21(1): 58-69. PMid:10706352 http://dx.doi .org/10.1097/00004703-200 002000-00011

[11] Francis L, Fitzpatrick JJ. Postoperative pain: Nurses' knowledge and patients' experiences. Pain Management Nursing. 2013; 14(4): 351-357. PMid:24315258 http://dx.doi.org/10.1016/j.pmn .2012 .05 .002

[12] Bristol-Myers S. Post Operative Pain. 2009. Available from: http: //www.bmsi.co.in/postoperative.aspx?section=3

[13] Dolin S, Cashman J, Bland J. Effectiveness of acute postoperative pain management: I. Evidence from published data. British Journal of Anaesthesia. 2002; 89(3): 409-423. PMid:12402719 http://dx.doi.org/10.1093/bja/89.3.409

[14] Michaels TK, et al. Evaluating an educational approach to improve pain assessment in hospitalized patients. Journal of Nursing Care Quality. 2007; 22(3): 260-265. PMid:17563596 http: //dx.doi.org/10.1097/01.NCQ.0000277784.14310.66

[15] Ramsay MA. Acute postoperative pain management. Proceedings (Baylor University. Medical Center). 2000; 13(3): 244. PMid:16389390

[16] Cousins MJ, Brennan F, Carr DB. Pain relief: A universal human right. Pain. 2004; 112(1-2): 1-4. PMid:15494176 http://dx.doi .org/10.1016/j.pain.2004.09.002

[17] Franck LS, Bruce E. Putting pain assessment into practice: why is it so painful? Pain Research \& Management: The Journal of the Canadian Pain Society. 2009; 14(1): 13.

[18] King RL. Nurses' perceptions of their pharmacology educational needs. Journal of Advanced Nursing. 2004; 45(4): 392-400. http: //dx.doi.org/10.1046/j.1365-2648.2003.02922.x

[19] International Association for the Study of Pain [IASP]. Jordan Initiative for Pain Management. 2010. Available from: http: //www.iasp-pain.org/files/Content/NavigationMenu/A dvocacy/InternationalPainSummit/JordanReport .pdf

[20] Jordan Pain Society. About us. 2015. Available from: http://www . jordanpainsociety.org/index.aspx

[21] Al-Khawaldeh OA, Al-Hussami M, Darawad M. Knowledge and attitudes regarding pain management among Jordanian nursing students. Nurse Education Today. 2013; 33(4): 339-345. PMid:23398912 http://dx.doi.org/10.1016/j.nedt.2013.01.006
[22] Al Khalaileh M, Al Qadire M. Pain management in Jordan: Nursing students' knowledge and attitude. British Journal of Nursing. 2013; 22(21): 1234-1240. PMid:24280924 http://dx.doi.org/10.12 968/bjon.2013.22.21.1234

[23] Chiu LH, et al. A study to evaluate the pain knowledge of two subpopulations of final year nursing students: Australia and Philippines. Journal of Advanced Nursing. 2003; 41(1): 99-108. PMid:12519293 http://dx.doi.org/10.1046/j.1365-2648.2003.02511.x

[24] Greenberger C, Reches H, Riba S. Levels and predictors of knowledge and attitudes regarding pain among Israeli baccalaureate nursing students and nurses pursuing specialty certification. International Journal of Nursing Education Scholarship. 2006; 3(1) PMid:16646951 http://dx.doi.org/10.2202/1548-923X.12 21

[25] Duke G, et al. Pain management knowledge and attitudes of baccalaureate nursing students and faculty. Pain Management Nursing. 2013; 14(1): 11-19. PMid:23452522 http://dx.doi.org/10.10 16/j.pmn.2010.03.006

[26] Chiang LC, Chen HJ, Huang L. Student nurses' knowledge, attitudes, and self-efficacy of children's pain management: Evaluation of an education program in Taiwan. Journal of Pain and Symptom Management. 2006; 32(1): 82-89. PMid:16824988 http: //dx.doi.org/10.1016/j.jpainsymman.2006.01.011

[27] Rahimi-Madiseh M, Tavakol M, Dennick R. A quantitative study of Iranian nursing students' knowledge and attitudes towards pain: Implication for education. International Journal of Nursing Practice. 2010; 16(5): 478-483. PMid:20854345 http://dx.doi.org/10 $1111 / \mathrm{j} .1440-172 \mathrm{X} .2010 .01872 . \mathrm{x}$

[28] Ali N, Thomson D. A comparison of the knowledge of chronic pain and its management between final year physiotherapy and medical students. European Journal of Pain. 2009; 13(1): 3850. PMid:18434220 http://dx.doi.org/10.1016/j.ejpain. 2008.02.005

[29] Watt-Watson J, et al. An integrated undergraduate pain curriculum, based on IASP curricula, for six health science faculties. Pain. 2004; 110(1): 140-148. PMid:15275761 http://dx.doi.org/10.1016 /j.pain. 2004.03.019

[30] Twycross A, Dowden SJ. Status of pediatric nurses' knowledge about pain. Pediatric Pain Letter. 2009; 11(3): 17-21.

[31] Loiselle CG, et al. Canadian essentials of nursing research. 2ed ed New York: Lippincott Williams and Wilkins; 2007.

[32] Levin KA. Study design III: Cross-sectional studies. Evidence-based dentistry. 2006; 7(1): 24-25. PMid:16557257 http://dx .doi .org $/ 10.1038 / \mathrm{sj}$.ebd. 6400375

[33] Manworren RC. Development and testing of the pediatric nurses' knowledge and attitudes survey regarding pain. Pediatric Nursing. 2001; 27(2): 151. PMid:12962251

[34] Stanley M, Pollard D. Relationship between knowledge, attitudes, and self-efficacy of nurses in the management of pediatric pain. Pediatric Nursing. 2013; 39(4): 165-171. PMid:24027950

[35] Lunsford L. Knowledge and Attitudes Regarding Pediatric Pain in Mongolian Nurses. Pain Management Nursing. 2014. PMid:25439122

[36] Plaisance L, Logan C. Nursing Students' Knowledge and Attitudes Regarding Pain. Pain Management Nursing. 2006; 7(4): 167 175. PMid:17145491 http://dx.doi.org/10.1016/j.pmn. 200 6.09 .003

[37] Johnston CC, et al. One-on-One Coaching to Improve Pain Assessment and Management Practices of Pediatric Nurses. Journal of Pediatric Nursing: Nursing Care of Children and Families. 2007; 22(6): 467-478. PMid:18036467 http://dx.doi.org/10.1016 /j.pedn.2007.07.004 
[38] Le May S, et al. Pain management practices in a pediatric emergency room (PAMPER) study: Interventions with nurses. Pediatric Emergency Care. 2009; 25(8): 498-503. PMid:19633588 http://dx.doi.org/10.1097/PEC.0b013e3181b0a0af

[39] Manworren RC. Pediatric nurses' knowledge and attitudes survey regarding pain. Pediatric Nursing. 2000; 26(6): 610. PMid:12026363

[40] Salanterä S, Lauri S. Nursing students' knowledge of and views about children in pain. Nurse Education Today. 2000; 20(7): 537 547. PMid:12173257 http://dx.doi.org/10.1054/nedt. 2000 .0472

[41] Tiernan E. A Survey of registered nurses' knowledge and attitudes regarding paediatric pain assessment and management: An irish perspective. Archives of Disease in Childhood. 2008; 93(Supplement 2): 18.

[42] Ekim A, Ocakcı AF. Knowledge and attitudes regarding pain management of pediatric nurses in Turkey. Pain Management Nursing 2013; 14(4): e262-e267. PMid:24315279 http://dx.doi.org/1 $0.1016 / j \cdot$ pmn. 2012.02 .004

[43] Ellis JA, et al. Implementing best practice pain management in a pediatric hospital. Journal for Specialists in Pediatric Nursing. 2007; 12(4): 264-277. PMid:17956374 http://dx.doi.org/10.1111 /j.1744-6155.2007.00121.x

[44] Vincent CVH. Nurses' perceptions of children's pain: A pilot study of cognitive representations. Journal of Pain and Symptom management. 2007; 33(3): 290-301. PMid:17349498 http://dx.doi.org /10.1016/j.jpainsymman.2006.08.008

[45] Ndosi ME, Newell R. Nurses' knowledge of pharmacology behind drugs they commonly administer. Journal of Clinical Nursing. 2009; 18(4): 570-580. PMid:18680489 http://dx.doi.org/10.1111 $/ \mathrm{j} .1365-2702.2008 .02290 \cdot \mathrm{x}$

[46] Grandell-Niemi H, et al. Finnish nurses' and nursing students' pharmacological skills. Journal of Clinical Nursing. 2005; 14(6): 685694. PMid:15946276 http://dx.doi.org/10.1111/j.1365-2 702.2005.01131.x

[47] Dilles T, et al. Nursing students' pharmacological knowledge and calculation skills: Ready for practice? Nurse Education Today. 2011; 31(5): 499-505. PMid:20837376 http://dx.doi.org/10.1016 /j.nedt.2010.08.009
[48] Hewitt P. Nurses' perceptions of the causes of medication errors: An integrative literature review. Medsurg Nursing. 2010; 19(3): 159-167.

[49] Blondal K, Halldorsdottir S. The challenge of caring for patients in pain: from the nurse's perspective. Journal of Clinical Nursing. 2009; 18(20): 2897-2906. PMid:19538556 http://dx . doi .org/10.11 11/j.1365-2702.2009.02794.x

[50] Richards J, Hubbert AO. Experiences of expert nurses in caring for patients with postoperative pain. Pain Management Nursing. 2007; 8(1): 17-24. PMid:17336866 http://dx.doi.org/10.1016/j ·p $\mathrm{mn} .2006 .12 .003$

[51] Schechter N, Berde C, Yaster M. Pain in infants, children, and adolescents. 2 ed. Philadelphia: Lippincott Williams \& Wilkins; 2003.

[52] Rieman MT, Gordon M. Pain management competency evidenced by a survey of pediatric nurses' knowledge and attitudes. Pediatric Nursing. 2007; 33(4): 307.

[53] Briggsl EV, Carrl EC, Whittakerl MS. Survey of undergraduate pain curricula for healthcare professionals in the United Kingdom. European Journal of Pain. 2011; 15(8): 789-795. PMid:21330174 http://dx.doi.org/10.1016/j.ejpain.2011.01.006

[54] Institute of Medicine. Relieving Pain in America: A Blueprint for Transforming Prevention, Care, Education, and Research. Washington, DC: National Academies Press; 2011.

[55] Initiative NPS. National pain strategy: pain management for all Australians. Melbourne: Faculty of Pain Medicine. 2010.

[56] Twycross A. Educating nurses about pain management: The way forward. Journal of Clinical Nursing. 2002; 11(6): 705-714. http: //dx.doi.org/10.1046/j.1365-2702.2002.00677.x

[57] Keyte D, Richardson C. Re-thinking pain educational strategies: Pain a new model using e-learning and PBL. Nurse Education Today. 2011; 31(2): 117-121. PMid:20566232 http://dx.doi.org/10. 1016/j.nedt.2010.05.001

[58] Yildirim YK, Cicek F, Uyar M. Knowledge and attitudes of Turkish oncology nurses about cancer pain management. Pain Management Nursing. 2008; 9(1): 17-25. PMid:18313586 http://dx.doi.org $/ 10.1016 / \mathrm{j} \cdot \mathrm{pmn} .2007 .09 .002$

[59] International Association for the Study of Pain [IASP]. IASP Curriculum Outline on Pain for Nursing. 2014. Available from: http://www.iasp-pain.org/Education/Curriculum Detail . aspx? ItemNumber $=2052$ 